\title{
Opracowanie metodyki oznaczania polichlorowanych bifenyli w próbkach gleb
}

\section{Development of a methodology for the determination of polychlorinated biphenyls in soil samples}

\author{
Katarzyna Wojtowicz, Piotr Jakubowicz \\ Instytut Nafty i Gazu - Państwowy Instytut Badawczy
}

\begin{abstract}
STRESZCZENIE: W artykule przedstawione zostały zagadnienia związane z opracowaniem metodyki chromatograficznego oznaczania polichlorowanych bifenyli w próbkach gleb. Do tego celu stosowano chromatograf gazowy wyposażony w detektor wychwytu elektronów (GC-ECD) firmy Perkin Elmer. W ramach prowadzonych badań określono optymalne parametry pracy chromatografu, takie jak: temperatura inżektora, temperatura detektora ECD, przebieg temperaturowy pieca w trakcie analizy chromatograficznej, czas analizy oraz dobrano kolumnę chromatograficzną umożliwiającą selektywny rozdział analitów. Następnie przeprowadzono kalibrację układu chromatograficznego i walidację metody analitycznej oznaczania polichlorowanych bifenyli, stosując roztwory wzorcowe firmy Supelco i Sigma-Aldrich o numerach odpowiednio 47330-U oraz 36989. Sporządzono krzywe kalibracyjne dla każdego z badanych kongenerów PCB (PCB-10, PCB-28, PCB-53, PCB-101, PCB-138, PCB-153, PCB-180, PCB-209) w dwóch zakresach stężeń. Walidacja metody analitycznej obejmowała wyznaczenie liniowości, odchylenia standardowego, względnego odchylenia standardowego, granicy wykrywalności (LOD) i granicy oznaczalności (LOQ) wyżej wymienionych kongenerów PCB. W tym celu opracowania metodyki przygotowania próbek gleb do analizy chromatograficznej przetestowano układ pod kątem doboru metody ekstrakcji (ekstrakcja rozpuszczalnikiem wspomagana wytrząsaniem, ekstrakcja z wykorzystaniem ultradźwięków i ekstrakcja w aparacie Soxhleta), doboru rozpuszczalnika/układu rozpuszczalników (n-heksan, mieszanina n-heksanu i dichlorometanu w stosunku 1:1) oraz doboru materiału sorpcyjnego w etapie ekstrakcji do fazy stałej SPE (kolumienki do zadań specjalnych oraz kolumienki z wypełnieniem Florisil). Do badań modelowych wykorzystano próbki gleb zanieczyszczone roztworem wzorcowym firmy Supelco o numerze 47330-U. Dla wszystkich kombinacji wyżej wymienionych warunków przygotowania próbki do analizy chromatograficznej obliczono stopień odzysku poszczególnych analitów. Na podstawie analiz chromatograficznych i stopni odzysku wytypowano najbardziej optymalną metodykę przygotowania próbek gleb do analizy chromatograficznej pod kątem oznaczania polichlorowanych bifenyli. Opracowaną metodykę oznaczania polichlorowanych bifenyli w próbkach gleb przetestowano na rzeczywistych próbkach gleb skażonych zestarzałym olejem transformatorowym pobranych $\mathrm{z}$ terenów południowo-wschodniej Polski. Procedura analityczna oznaczania PCB w próbkach gleby obejmowała: wstępne przygotowanie próbek (suszenie, mielenie i homogenizacja), izolację analitów z matrycy próbki (ekstrakcja rozpuszczalnikiem wspomagana wytrząsaniem z zastosowaniem mieszaniny rozpuszczalników n-heksan:dichlorometan w stosunku 1:1), oczyszczanie próbki z substancji przeszkadzających (zestaw dwóch kolumienek do ekstrakcji SPE: Silica gel nr 7086-03 i PCB-A nr 7511-04 firmy Bakerbond), analizę chromatograficzną. Zastosowanie wyżej wymienionych technik analitycznych pozwoliło na uzyskanie informacji na temat zawartości badanych kongenerów polichlorowanych bifenyli w próbkach gleb.
\end{abstract}

Słowa kluczowe: polichlorowane bifenyle, chromatografia gazowa, detektor wychwytu elektonów (ECD), ekstrakcja, ekstrakcja do fazy stałej SPE.

ABSTRACT: The article presents issues related to the development of the chromatographic methodology for determining polychlorinated biphenyls in soil samples. For this purpose, a gas chromatograph equipped with an electron capture detector (GC-ECD) from Perkin Elmer was used. As part of the research, optimal chromatograph parameters were determined, such as injector temperature, ECD detector temperature, oven temperature course during chromatographic analysis, time of analysis and a chromatographic column allowing selective separation of analytes. Then, the chromatographic system was calibrated and the analytical method for polychlorinated biphenyls determination was validated, based on the Supelco and Sigma-Aldrich reference solutions with numbers 47330-U and 36989, respectively. Calibration curves for each of the congeners tested were PCB (PCB-10, PCB-28, PCB-53, PCB-101, PCB-138, PCB-153, PCB-180, PCB-209) in two concentration ranges. The validation of the analytical method included the determination of linearity, standard deviation, relative standard deviation, detection limit (LOD) and limit of quantification (LOQ) of the above PCB

Autor do korespondencji: K. Wojtowicz, e-mail: wojtowiczk@inig.pl

Artykuł nadesłano do Redakcji 13.12.2018 r. Zatwierdzono do druku 4.06.2019 r. 
congeners. To this end, the development of the methodology for preparing soil samples for chromatographic analysis has been tested for the selection of the extraction method (extraction with solvent assisted by shaking, extraction with ultrasonic assisted solvent, solvent extraction in a Soxhlet apparatus), solvent/solvent system selection (n- hexane, a mixture of n-hexane and dichloromethane in a 1:1 ratio) and selection of sorption material in the SPE solid phase extraction stage (columns for special tasks, Florisil packed columns). Model samples used soil contaminated with the Supelco standard solution number 47330-U. For all the combinations of the above-mentioned conditions of preparing the sample for chromatographic analysis, the recovery rate of individual analytes was calculated. On the basis of chromatographic analyses and recovery levels, the most optimal methodology for preparing soil samples for chromatographic analysis was selected for the determination of polychlorinated biphenyls. The developed methodology for the determination of polychlorinated biphenyls in soil samples was tested on real samples of soils contaminated with aged transformer oil taken from the areas of south-eastern Poland. The analytical procedure for the determination of PCBs in soil samples included: initial sample preparation (drying, milling, homogenization), isolation of analytes from the sample matrix (solvent extraction assisted by shaking with a 1:1 mixture of solvents n-hexane: dichloromethane), sample purification from disturbing substances (a set of two columns for SPE extraction: Silica gel No. 7086-03 and PCB-A No. 7511-04 from Bakerbond), chromatographic analysis. The application of the above-mentioned analytical techniques allowed to obtain information on the content of polychlorinated biphenyls investigated in soils samples.

Key words: polychlorinated biphenyls, gas chromatography, electron capture detector (ECD), extraction, solid phase extraction SPE.

\section{Wprowadzenie}

Polichlorowane bifenyle uznawane są za modelowy wskaźnik zanieczyszczenia środowiska przyrodniczego średnio lotnymi związkami organicznymi. Zróżnicowanie zarówno ilościowe, jak i jakościowe oznaczanych kongenerów PCB w poszczególnych składnikach środowiska jest konsekwencją zróżnicowanej budowy chemicznej, właściwości fizycznych i chemicznych, szybkości wchłaniania, metabolizmu, wydalania i rozpadu poszczególnych kongenerów, a także pochodną lokalnego skażenia środowiska, długości życia oraz indywidualnego sposobu odżywiania (Erickson, 1997). Dodatkowo chiralne PCB traktowane są jako wskaźniki przemian biochemicznych w środowisku, a enancjoselektywne oznaczanie atropoizomerów sprzyja identyfikacji i różnicowaniu źródeł zanieczyszczenia tymi ksenobiotykami (Lehmler i Robertson, 2001; Lehmler et al., 2010; Faroon i Ruiz, 2016; Kania-Korwel i Lehmler, 2016). Przegląd prac opublikowanych na przełomie ostatnich lat wykazuje dużą rozbieżność w metodyce oznaczania polichlorowanych bifenyli w próbkach środowiskowych. Jest ona konsekwencją złożoności matryc środowiskowych oraz właściwości poszczególnych kongenerów PCB. W celu uzyskania wiarygodnych wyników badań istotne jest usystematyzowanie i opracowanie optymalnej metodyki analitycznej w zakresie oznaczania PCB.

Metody chromatograficznego rozdziału i oznaczania substancji w próbkach osiągnęły taki stopień rozwoju i możliwości, że są jednymi z najbardziej rozpowszechnionych metod instrumentalnych w chemii analitycznej. Tak wysoką pozycję wśród metod analitycznych chromatografia uzyskała dzięki możliwości wykrywania substancji analizowanej i oznaczania jej ilości w próbce na bardzo niskim poziomie stężeń w obecności innych składników (Witkiewicz, 2005). Oznaczenia polichlorowanych bifenyli prowadzone są najczęściej metodą chromatografii gazowej z detektorem wychwytu elektronów (GC-ECD) lub masowym (GC-MS). Biorąc pod uwagę dane literaturowe oraz zaplecze laboratoryjne, którym dysponuje Zakład Technologii Eksploatacji Płynów Złożowych INiG - PIB, Oddział Krosno do oznaczania polichlorowanych bifenyli w próbkach gleb wykorzystano metodę chromatografii gazowej z detekcją ECD.

Detektor wychwytu elektronów odgrywa istotną rolę w ochronie i kontroli środowiska przyrodniczego. Wykorzystanie go w analizach środowiskowych pozwoliło udowodnić powszechną obecność polichlorowanych bifenyli, pestycydów oraz halogenowęglowodorów we wszystkich biotycznych i abiotycznych elementach przyrody. Ponadto uświadomiło problem globalnego zasięgu zanieczyszczeń chloroorganicznych, które wykazują właściwości mutagenne i kancerogenne (Śliwka, 2014). Detektor ten jest jednym z najczęściej stosowanych detektorów w chromatografii gazowej i znajduje szerokie zastosowanie w naukach medycznych, biomedycznych, farmacji oraz w wielu zagadnieniach analitycznych. Stosowany jest przede wszystkim w analizach pestycydów chlorowcowych, fosforowych, polichlorowanych bifenyli, herbicydów, alkoholi, estrów azotanowych i wielu innych związków, w tym organicznych i nieorganicznych (Ševĉ́k, 1976; Śliwka, 2014). Dzięki wysokiej selektywności i czułości w stosunku do związków chlorowcowych oraz ich niskiej granicy wykrywalności, obszar zastosowań metod analitycznych z zastosowaniem detektora ECD stale się poszerza (Śliwka, 2014).

\section{Opracowanie metodyki chromatograficznego oznaczania PCB}

Oznaczanie polichlorowanych bifenyli w próbkach środowiskowych najczęściej prowadzone jest metodami chromatografii gazowej z wykorzystaniem detekcji wychwytu 
elektronów (GC-ECD) oraz masowej GC-MS. Do analizy PCB zastosowano chromatograf Clarus 500 wyposażony w detektor ECD (GC-ECD) firmy Perkin Elmer, którym dysponuje Zakład Technologii Eksploatacji Płynów Złożowych INiG - PIB. W ramach opracowania metodyki badawczej chromatograficznego oznaczania polichlorowanych bifenyli w próbkach środowiskowych określono optymalne parametry pracy chromatografu (Wojtowicz, 2018), takie jak: temperatura inżektora $=280^{\circ} \mathrm{C}$, temperatura detektora $\mathrm{ECD}=320^{\circ} \mathrm{C}$, przebieg temperaturowy pieca: $120^{\circ} \mathrm{C}$ - przebieg izotermiczny przez 2 min, przyrost temperatury od $120^{\circ} \mathrm{C}$ do $280^{\circ} \mathrm{C}$ z szybkością $15^{\circ} \mathrm{C} / \mathrm{min}, 280^{\circ} \mathrm{C}$ - przebieg izotermiczny przez $5 \mathrm{~min}$, przyrost temperatury od $280^{\circ} \mathrm{C}$ do $320^{\circ} \mathrm{C} \mathrm{z}$ szybkością $28^{\circ} \mathrm{C} / \mathrm{min}$, $320^{\circ} \mathrm{C}$ - przebieg izotermiczny przez $10 \mathrm{~min}$. Ilościowe oznaczenie całkowitej zawartości PCB technikami chromatograficznymi jest trudnym zagadnieniem w analizie środowiskowej, dlatego ze względów praktycznych oznacza się zazwyczaj jedynie tak zwane kongenery indykatorowe (PCB nr 28, 52, 101, 138, 153 i 180) (Tian et al., 2016; Ficek i Czupioł, 2018). Na podstawie zawartości wyżej wymienionych kongenerów szacuje się całkowitą zawartość PCB w próbce. Kolejnym istotnym problemem oznaczania metodą chromatografii gazowej kongenerów PCB jest to, że są one mieszaninami wieloskładnikowymi (Zhang et al., 2013; Stella et al. 2015; Vazquez-Roig i Pico, 2015). Ważny jest zatem dobór odpowiedniej kolumny z właściwie przygotowaną powierzchnią wewnętrzną, pokrytą termostabilną fazą organiczną o precyzyjnie dobranych właściwościach fizykochemicznych, w tym polarności (Oznaczanie polichlorowanych difenyli, 2018). W wyniku przeprowadzonych badań, mających na celu optymalizację metody, wybrano kapilarną kolumnę chromatograficzną RTX-XLB firmy Restek wypełnioną stopioną krzemionką o wymiarach $30 \mathrm{~m} \times 0,32 \mu \mathrm{m}$ oraz wytrzymałości termicznej $340^{\circ} \mathrm{C}$, charakteryzującą się dobrą selektywności w stosunku do polichlorowanych bifenyli.

\section{Kalibracja uktadu chromatograficznego}

Kalibracja polega na przedstawieniu zależności sygnału analitycznego od stężenia analitu i wykorzystaniu tej zależności do wyznaczenia stężenia analitu w próbce (Kania i Janiga, 2011). Kalibrację układu chromatograficznego pod względem oznaczania polichlorowanych bifenyli przeprowadzono stosując roztwory wzorcowe firmy Supelco i Sigma-Aldrich o stężeniach $10 \mu \mathrm{g} / \mathrm{ml}$ każdego składnika w izooktanie o numerach odpowiednio 47330-U oraz 36989. Sam proces kalibracji nie wchodzi w skład procedury walidacyjnej metodyki, ale jego wykonanie jest niezbędne do wyznaczenia podstawowych parametrów walidacyjnych, np. liniowości, granicy wykrywalności itp. Celem kalibracji jest minimalizacja błędów pomiarowych, czyli kontrola i zapewnienie odpowiedniej jakości uzyskanych wyników (Kania i Janiga, 2011). Przed wprowadzeniem nowej metody analitycznej konieczne jest zatem jej sprawdzenie w laboratorium w trakcie badań modelowych z wykorzystaniem próbek odpowiednio przygotowanych i przechowywanych roztworów wzorcowych. Krytycznym punktem w analizie ilościowej PCB techniką GC-ECD jest konieczność pracy w zakresie liniowej odpowiedzi detektora. Aby określić przedział stężeń analitów, które mogą być oznaczone przy użyciu chromatografii gazowej z detekcją ECD, zbadano odpowiedź detektora na wzrastające stężenia/ilości każdego z kongenerów zawartych próbkach (PCB-10, PCB-28, PCB-53, PCB-101, PCB-138, PCB-153, PCB-180, PCB-209) (Szlęk i Król, 2013). Wykorzystując roztwory wzorcowe przygotowano serię 13 próbek kalibracyjnych o stężeniach poszczególnych kongenerów PCB w izooktanie, równych: 0, 1, 5, 10, 50, 100, 200, 500, 1000, 2500, 5000, 7500, $10000 \mu \mathrm{g} / \mathrm{dm}^{3}$. Tak szeroki zakres stosowania metody wynika z faktu, że polichlorowane bifenyle w zależności od źródła i rodzaju skażenia mogą występować w środowisku w różnych ilościach. $\mathrm{Na}$ podstawie przeprowadzonych analiz i danych analitycznych uzyskanych w programie TotalChrom wykreślono dla każdego z kongenerów PCB krzywe kalibracyjne będące zależnością powierzchni piku wyrażoną w $\mu V \cdot s$ od stężenia wyrażonego $\mathrm{w} \mathrm{mg} / \mathrm{dm}^{3}$. Ze względu na szeroki zakres analizowanych stężeń, zdecydowano się na sporządzenie 2 krzywych kalibracyjnych dla każdego analizowanego kongeneru PCB w różnych zakresach stężeń. Ponadto dla każdego badanego kongeneru PCB wyznaczono miejsce przecięcia krzywych kalibracyjnych, na podstawie którego możliwe jest określenie, z jakiego równania krzywej należy skorzystać podczas oznaczeń ilościowych. Pozwoliło to na znaczne zmniejszenie błędów pomiarowych szczególnie w próbkach o bardzo małych oraz bardzo dużych stężeniach polichlorowanych bifenyli. Zarówno w przypadku krzywych kalibracyjnych sporządzonych dla niskich, jak i wysokich zakresów stężeń do ich opisu zastosowano wielomian I stopnia $y=a x+b$, który wystarczająco dobrze odwzorowywał zależność wielkości sygnału detektora wychwytu elektronów od stężenia oznaczanych kongenerów PCB (Wojtowicz, 2018). Współczynniki regresji zawierały się w przedziale od 0,9975 do 1,0000 dla małych stężeń polichlorowanych bifenyli w próbce oraz $\mathrm{w}$ przedziale od 0,9996 do 1,0000 dla dużych stężeń PCB. Duże wartości współczynników regresji (tab. 1) analizowanych kongenerów PCB świadczą o dobrym dopasowaniu liniowym. Przykładowe krzywe kalibracyjne sporządzone dla kongeneru PCB nr 138 oraz ich miejsce przecięcia przedstawiono na rysunkach 1 i 2 .

W wyniku doboru optymalnych warunków chromatograficznych uzyskano rozdział oznaczanych kongenerów PCB w próbce wzorcowej, który został przedstawiony na rysunku 3. 
Tabela 1. Zestawienie krzywych kalibracyjnych stosowanych do obliczeń ilościowych PCB w próbkach gleby oraz współczynników regresji

Table 1. A comparison of calibration curves used for quantitative calculations of PCBs in soil samples and regression coefficients

\begin{tabular}{|c|c|c|c|c|c|}
\hline \multirow{2}{*}{ Skkladnik } & \multicolumn{2}{|c|}{ Równanie krzywej kalibracyjnej } & \multicolumn{2}{c|}{ Współczynnik regresji $R^{2}$} & $\begin{array}{c}\text { Miejsce przecięcia } \\
\text { krzywych } \\
\text { kalibracyjnych }\end{array}$ \\
\cline { 2 - 6 } & niski zakres stężeń & wysoki zakres stężeń & niski zakres stężeń & wysoki zakres stężeń & $R^{2}=0,9998$ \\
$(191,7925 ; 10691,8565)$ \\
\hline \hline PCB-10 & $\mathrm{y}=55,747 \mathrm{x}+49,515$ & $\mathrm{y}=28,026 \mathrm{x}+5416,6$ & $R^{2}=0,9998$ & $R^{2}=0,9999$ & $(46,8457 ; 3755,0620)$ \\
\hline PCB-28 & $\mathrm{y}=79,812 \mathrm{x}+15,213$ & $\mathrm{y}=49,579 \mathrm{x}+1431,5$ & $R^{2}=0,9999$ & $R^{2}=1$ & $(90,6373 ; 4390,9450)$ \\
\hline PCB-52 & $\mathrm{y}=49,446 \mathrm{x}-90,709$ & $\mathrm{y}=29,474 \mathrm{x}+1719,5$ & $R^{2}=1$ & $R^{2}=0,9999$ & $(92,4909 ; 7066,3003)$ \\
\hline PCB-101 & $\mathrm{y}=74,844 \mathrm{x}+143,91$ & $\mathrm{y}=42,362 \mathrm{x}+3148,2$ & $R^{2}=0,9975$ & $R^{2}=1$ & $(203,0154 ; 18862,3756)$ \\
\hline PCB-138 & $\mathrm{y}=97,276 \mathrm{x}+128,93$ & $\mathrm{y}=65,523 \mathrm{x}+5560,2$ & $R^{2}=0,9999$ & $R^{2}=0,9997$ & $(177,6219 ; 16039,9742)$ \\
\hline PCB-153 & $\mathrm{y}=89,91 \mathrm{x}+69,991$ & $\mathrm{y}=70,083 \mathrm{x}+3591,7$ & $R^{2}=0,9994$ & $R^{2}=0,9996$ & $(244,4979 ; 42227,8294)$ \\
\hline PCB-180 & $\mathrm{y}=171,85 \mathrm{x}+210,86$ & $\mathrm{y}=123,53 \mathrm{x}+12025$ & $R^{2}=0,9998$ & $R^{2}=0,9998$ & $(220,2454 ; 37193,7343)$ \\
\hline PCB-209 & $\mathrm{y}=168,48 \mathrm{x}+86,797$ & $\mathrm{y}=97,876 \mathrm{x}+15637$ & $R^{2}=1$ & &
\end{tabular}
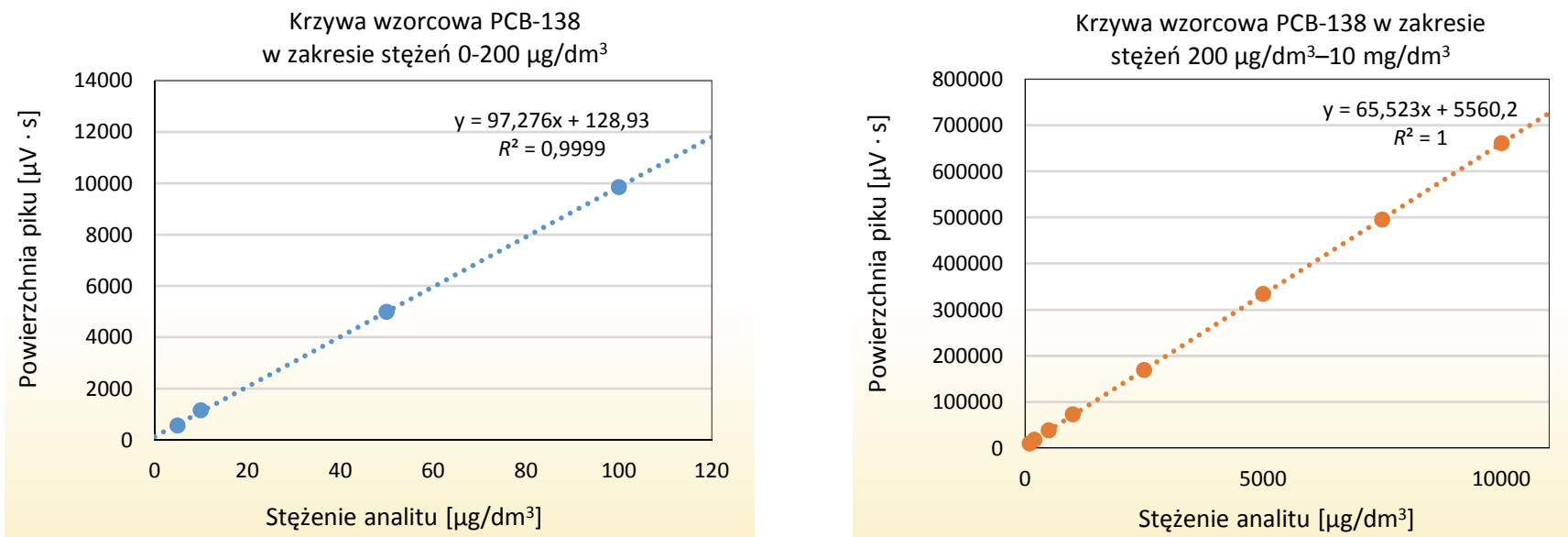

Rys. 1. Przykładowe krzywe kalibracyjne dla związku PCB-138 w zakresie niskich i wysokich stężeń

Fig. 1. Sample calibration curves for the PCB-138 compound in the low and high concentration range

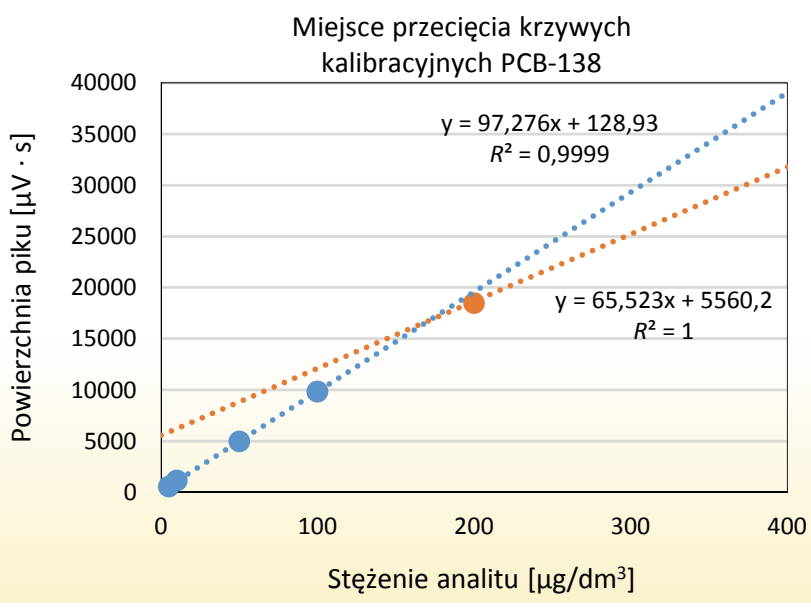

Rys. 2. Miejsce przecięcia krzywych kalibracyjnych PCB-138

Fig. 2. Intersection of calibration curves PCB-138

\section{Walidacja metodyki badawczej}

Zgodnie z definicją walidacja to potwierdzenie, przez zbadanie i przedstawienie obiektywnego dowodu, że zostały spełnione szczególne wymagania dotyczące konkretnie zamierzonego zastosowania (Kania i Janiga, 2011). Dlatego kluczową sprawą przy określaniu wiarygodności chromatograficznej metodyki analitycznej jest zbadanie dokładności, precyzji i powtarzalności wykonywanych oznaczeń. W celu przetestowania metody chromatograficznego oznaczania polichlorowanych bifenyli, wykonano drugą serię analiz posługując się roztworami wzorcowymi firmy Supelco nr 47330-U oraz Sigma-Aldrich nr 36989. Dla każdej serii wykonano po 10 pomiarów dla stężenia $10 \mathrm{mg} / \mathrm{dm}^{3}$ i $100 \mu \mathrm{g} / \mathrm{dm}^{3}$ każdego $\mathrm{z}$ badanych kongenerów PCB. Przy obliczaniu ilościowym PCB brano pod uwagę uprzednio sporządzone krzywe kalibracyjne. Na podstawie uzyskanych wyników obliczono wartości: odchylenia standardowego, względnego odchylenia standardowego, średniej wartości stężeń, średniego odzysku oraz błędów względnych. Analizując otrzymane wyniki można stwierdzić, że testowany układ chromatograficzny charakteryzuje się dużą powtarzalnością oznaczeń w badanych zakresach stężeń, czego dowodem jest fakt, że żaden $\mathrm{z}$ otrzymanych wyników analiz PCB nie odbiega o więcej niż trzykrotną wartość odchylenia standardowego. 


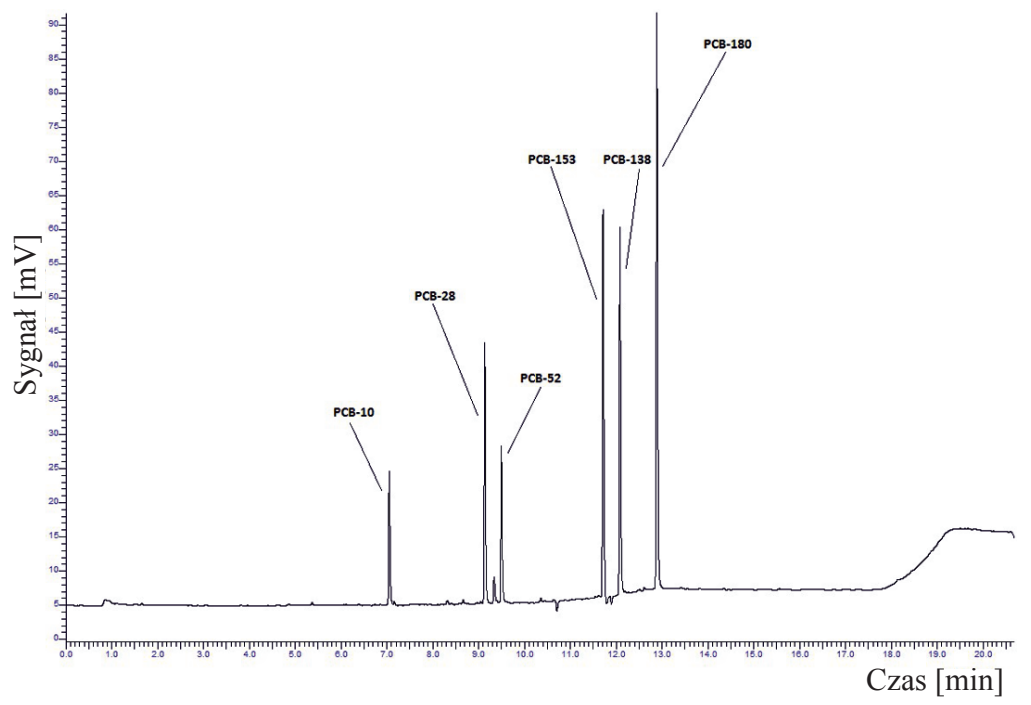

Rys. 3. Chromatogram rozdziału polichlorowanych bifenyli w próbce wzorcowej o stężeniu poszczególnych kongenerów PCB równym $1 \mathrm{mg} / \mathrm{dm}^{3}$ (wzorzec 47330-U)

Fig. 3. Chromatogram of the distribution of polychlorinated biphenyls in a standard sample with a concentration of individual PCB congeners equal to $1 \mathrm{mg} / \mathrm{dm}^{3}$ (standard $47330-\mathrm{U}$ )

Obliczone wartości względnego odchylenia standardowego, które są miarą precyzji metody analitycznej zawierają się w granicach od 1,4398 do $1,8161 \%$ w roztworze o stężeniu każdego ze składników wynoszącym $10 \mathrm{mg} / \mathrm{dm}^{3}$ oraz od 1,1097 do 1,4574\% w roztworze o stężeniu badanych kongenerów PCB wynoszącym $100 \mu \mathrm{g} / \mathrm{dm}^{3}$. Wysokie wartości średniego odzysku alitów, wynoszące powyżej $95 \%$ oraz niskie wartości błędów względnych $(0,0258-0,0349$ - dla stężeń
$100 \mu \mathrm{g} / \mathrm{dm}^{3}$ i 0,0230-0,0355 - dla stężeń $10 \mathrm{mg} / \mathrm{dm}^{3}$ ) świadczą o wysokiej dokładności opracowanej metody. Zestawienie obliczonych parametrów walidacyjnych dla badanych kongenerów PCB zamieszczono w tabeli 2.

Kolejnym istotnym parametrem walidacyjnym jest zakres stosowania opracowanej metody chromatograficznego oznaczania polichlorowanych bifenyli. O zakresie stosowania każdej metody chromatograficznej decyduje rodzaj zastosowanego detektora, a dokładnie jego zakres i czułość. W przypadku oznaczania PCB zastosowano detektor wychwytu elektronów charakteryzujący się niską granicą wykrywalności w stosunku do związków chloroorganicznych. To właśnie granica wykrywalności oraz granica oznaczalności decydują o zakresie stosowania danej metody analitycznej. Granica wykrywalności (LOD) to najmniejsze stężenie (ilość) analitu możliwe do wykrycia za pomocą danej procedury analitycznej z określonym prawdopodobieństwem. Granica oznaczalności (LOQ) definiowana jest natomiast jako najmniejsze stężenie (ilość) substancji możliwe do ilościowego oznaczenia za pomocą danej procedury analitycznej z założoną dokładnością i precyzją (Kania i Janiga, 2011; Szlęk i Król, 2013). Wartości granicy wykrywalności i granicy oznaczalności każdego z badanych kongenerów PCB obliczono wykorzystując równania 1 i 2 (Kruszewska, 2018):

$$
\operatorname{LOD}=\frac{3,3 \cdot s}{b}
$$

Tabela 2. Zestawienie parametrów walidacyjnych w roztworach wzorcowych o stężeniach $100 \mu \mathrm{g} / \mathrm{dm}^{3}$ i $10 \mathrm{mg} / \mathrm{dm}^{3}$

Table 2. Comparison of validation parameters in standard solutions at concentrations of $100 \mu \mathrm{g} / \mathrm{dm}^{3} \mathrm{and} 10 \mathrm{mg} / \mathrm{dm}^{3}$

\begin{tabular}{|l|c|c|c|c|c|c|c|c|}
\hline \multicolumn{1}{|c|}{ Oznaczany parametr } & PCB-10 & PCB-28 & PCB-52 & PCB-101 & PCB-137 & PCB-153 & PCB-180 & PCB-209 \\
\hline \hline $\begin{array}{l}\text { Stężenie w roztworze } \\
\text { wzorcowym }\left[\mu \mathrm{g} / \mathrm{dm}^{3}\right]\end{array}$ & 100 & 100 & 100 & 100 & 100 & 100 & 100 & 100 \\
\hline Wartość średnia $\left[\mu \mathrm{g} / \mathrm{dm}^{3}\right]$ & 96,5093 & 97,4211 & 97,0621 & 96,7086 & 97,0556 & 96,8468 & 97,2608 & 96,9813 \\
\hline Odchylenie standardowe & 1,4065 & 1,2933 & 1,1632 & 1,2785 & 1,1865 & 1,2415 & 1,0793 & 1,3766 \\
\hline $\begin{array}{l}\text { Względne odchylenie } \\
\text { lstandardowe [\%] }\end{array}$ & 1,4574 & 1,3275 & 1,1984 & 1,3220 & 1,2225 & 1,2819 & 1,1097 & 1,4194 \\
\hline Średni odzysk [\%] & 96,51 & 97,42 & 97,06 & 96,71 & 97,06 & 96,85 & 97,26 & 96,98 \\
\hline Błąd względny & 0,0349 & 0,0258 & 0,0294 & 0,0329 & 0,0294 & 0,0315 & 0,0274 & 0,0302 \\
\hline \hline $\begin{array}{l}\text { Stężenie w roztworze } \\
\text { wzorcowym [mg/dm } 3\end{array}$ & 10 & 10 & 10 & 10 & 10 & 10 & 10 & 10 \\
\hline Wartość średnia [mg/dm $\left.{ }^{3}\right]$ & 9,7225 & 9,6554 & 9,7260 & 9,7280 & 9,7110 & 9,6446 & 9,7695 & 9,6987 \\
\hline $\begin{array}{l}\text { Odchylenie standardowe } \\
(\text { RSD) }\end{array}$ & 0,1657 & 0,1638 & 0,1481 & 0,1434 & 0,1410 & 0,1389 & 0,1603 & 0,1761 \\
\hline $\begin{array}{l}\text { Względne odchylenie } \\
\text { standardowe [\%] }\end{array}$ & 1,7046 & 1,6967 & 1,5226 & 1,4742 & 1,4524 & 1,4398 & 1,6411 & 1,8161 \\
\hline Średni odzysk [\%] & 97,23 & 96,55 & 97,26 & 97,28 & 97,11 & 96,45 & 97,70 & 96,98 \\
\hline Błąd względny & 0,0278 & 0,0345 & 0,0274 & 0,0272 & 0,0289 & 0,0355 & 0,0230 & 0,0301 \\
\hline
\end{tabular}




$$
\mathrm{LOQ}=\frac{10 \cdot s}{b}
$$

gdzie:

$s$ - odchylenie standardowe dla ślepej próby (próbki gleby wolnej od PCB),

$b$ - nachylenie prostej kalibracyjnej.

Wyznaczone wartości LOD i LOQ zamieszczono w tabeli 3.

Tabela 3. Granice wykrywalności (LOD) i oznaczalności (LOQ) badanych kongenerów PCB

Table 3. Limits of detection (LOD) and quantification (LOQ) of the PCB congeners tested

\begin{tabular}{|c|c|c|}
\hline \multirow{2}{*}{$\begin{array}{c}\text { Kongener } \\
\text { PCB }\end{array}$} & $\begin{array}{c}\text { Granica } \\
\text { wykrywalności (LOD) }\end{array}$ & $\begin{array}{c}\text { Granica } \\
\text { oznaczalności (LOQ) }\end{array}$ \\
\cline { 2 - 3 }$\left[\boldsymbol{\mu} / \mathbf{d m}^{3}\right]$ & {$\left[\mu \mathrm{g} / \mathbf{d m}^{3}\right]$} \\
\hline \hline PCB-10 & 0,0183 & 0,0554 \\
\hline PCB-28 & 0,0285 & 0,0864 \\
\hline PCB-52 & 0,0106 & 0,0321 \\
\hline PCB-101 & 0,0041 & 0,0124 \\
\hline PCB-138 & 0,0042 & 0,0129 \\
\hline PCB-153 & 0,0074 & 0,0225 \\
\hline PCB-180 & 0,0029 & 0,0088 \\
\hline PCB-209 & 0,0099 & 0,0301 \\
\hline
\end{tabular}

\section{Zastosowanie metodyki chromatograficznego oznaczania składników w próbkach gleb}

Oznaczanie polichlorowanych bifenyli w próbkach środowiskowych stanowi nie lada wyzwanie dla współczesnej analityki. Ze względu na skomplikowany skład tego typu próbek pełna procedura badawcza składa się z kilku etapów, do których należą (Kluk i Steliga, 2017):

- pobieranie i wstępne przygotowanie próbki;

- izolacja analitów z matrycy;

- oczyszczanie próbki z substancji przeszkadzających;

- analiza chromatograficzna.

Każdy z wyżej wymienionych etapów jest przy tym bardzo złożony, czaso- i pracochłonny. Należy pamiętać, że w trakcie każdej z tych faz istnieje ryzyko strat analitów, wprowadzenia zanieczyszczeń i popełnienia błędów, dlatego podczas pracy z próbkami środowiskowymi należy zachować szczególną staranność i dokładność (Grochowalski, 2003).

\section{Material badawczy}

Materiał badawczy stanowiły próbki gleb zanieczyszczone kongenerami PCB o znanym stężeniu poszczególnych analitów. Próbki te uzyskano poprzez wprowadzenie do gleby wolnej od polichlorowanych bifenyli odpowiedniej ilości wzorca PCB (Supelco nr 47330-U) o stężeniu każdego z analitów wynoszącym $10 \mathrm{mg} / \mathrm{dm}^{3}$. W ten sposób uzyskany materiał doprowadzono do stanu powierzchnie suchego, zmielono, a następnie przesiano przez sito o średnicy oczek $1 \mathrm{~mm}$. Do każdej analizy pobierano po 5 gramów suchej gleby.

\section{Izolacja analitów z matrycy glebowej}

Chromatograficzna metoda identyfikacji PCB w próbkach gleby wymaga przeprowadzenia analitów z próbki stałej do matrycy ciekłej (etap izolacji) oraz zwiększenia stężenia analitów do poziomu wyższego niż granica oznaczalności stosowanych urządzeń (etap wzbogacania). Izolacje analitów z gleby prowadzi się przede wszystkim metodami ekstrakcyjnymi. Badania modelowe mające na celu określenie najbardziej optymalnej metody ekstrakcji polichlorowanych bifenyli z matrycy glebowej przeprowadzono stosując o trzy metody ekstrakcji: ekstrakcję rozpuszczalnikiem wspomaganą wytrząsaniem, ekstrakcję z wykorzystaniem ultradźwięków oraz ekstrakcję w aparacie Soxhleta (Vane et al., 2014; Pohl et al., 2016). Podczas każdej z testowanych metod ekstrakcji stosowano dwa różne warianty rozpuszczalnika: n-heksan (Lászlova et al., 2018) i n-heksan:dichlorometan w stosunku 1:1 (Pohl et al., 2016). W każdym przypadku do próbki gleby dodano $0,5 \mathrm{~g}$ sproszkowanej miedzi w celu usunięcia siarki z próbki (Halfadji et al., 2014, Saija et al., 2016).

\section{Oczyszczanie próbki z substancji przeszkadzających}

Kolejnym etapem procedury analitycznej oznaczania PCB w próbkach gleby jest oczyszczanie analitów z substancji przeszkadzających. Uzyskany ekstrakt jest silnie zanieczyszczony i nie może być w takiej postaci poddany analizie chromatograficznej. Oczyszczanie ekstraktu polega na rozdzieleniu i usunięciu substancji przeszkadzających, które niejednokrotnie mogą występować $\mathrm{w}$ próbce $\mathrm{w}$ dużych stężeniach (Kluk i Steliga, 2017). Niezwykle istotne w przypadku analizy PCB metodą chromatografii gazowej z detekcją ECD jest usunięcie z próbki związków siarki. Ma to na celu przede wszystkim ochronę detektora oraz redukcję zaburzenia sygnału analitycznego badanej substancji, a w konsekwencji zmniejszenie błędu analitycznego. Metodą rekomendowaną do usuwania siarki z próbek w analizie PCB, jest dodanie sproszkowanej miedzi do próbki w trakcie ekstrakcji lub do uzyskanego ekstraktu. Do usuwania pozostałych substancji przeszkadzających dogodną a zarazem dokładną metodą jest ekstrakcja na złożu sorpcyjnym SPE. W trakcie przeprowadzonych badań porównawczych wykorzystano dwa rodzaje kolumienek do ekstrakcji SPE: nowego typu kolumienki do zadań specjalnych firmy Bakerbond składający się z układu dwóch kolumienek: Silica gel nr 7086-03 i PCB-A nr 7511-04 oraz kolumienki Florisil nr 7213-03 również firmy Bakerbond (Pohl et al, 2016). 


\section{Analiza chromatograficzna}

W celu określenia najbardziej optymalnej metody przygotowania próbki gleby skażonej PCB, wykonano analizę chromatograficzną uzyskanych ekstraktów, obejmującą identyfikację oraz ilościowe oznaczenie polichlorowanych bifenyli. Analizę chromatograficzną każdej próbki wykonano na chromatografie Clarus 500 GC firmy Perkin Elmer, przy uprzednio ustalonych parametrach pracy chromatografu. Na podstawie przeprowadzonych analiz i danych analitycznych uzyskanych z programu TotalChrom obliczono średnie wartości stopni odzysku wybranych kongenerów PCB przy wykorzystaniu różnych technik przygotowania próbki (tab. 4). Przykładowy chromatogram rozdziału PCB we wzorcowej próbce gleby zamieszczono na rysunku 4 .

Niezależnie od sposobu przygotowania próbek do analizy chromatograficznej wyekstrahowano każdy z badanych kongenerów PCB. Na podstawie uzyskanych wyników analiz chromatograficznych badanych próbek oraz stopni odzysku wybranych kongenerów PCB stwierdzono, że najbardziej optymalną metodą przygotowania próbek gleby do analizy chromatograficznej pod kątem oznaczania PCB jest zastosowanie ekstrakcji rozpuszczalnikiem wspomaganej wytrząsaniem. W przeprowadzonych badaniach porównano również efektywność ekstrakcji PCB z matrycy glebowej wykorzystując n-heksan i mieszaninę $\mathrm{n}$-heksanu i dichlorometanu (1:1). Z obliczonych wartości stopnia odzysku analitów wynika, że najlepsze rezultaty otrzymuje się stosując mieszaninę rozpuszczalników n-heksanu i dichlorometanu w stosunku 1:1. Ostatnim aspektem sprawdzonym podczas określenia najbardziej optymalnej metody przygotowania próbek gleb zanieczyszczonych PCB do analizy chromatograficznej, było oczyszczanie otrzymanego ekstraktu na kolumienkach SPE. Porównując uzyskane wartości stopnia odzysku oraz wyniki analiz chromatograficznych stwierdzono, że najlepsze oczyszczenie próbki osiągnięto na zestawie kolumienek do zadań specjalnych firmy Bakerbond. Ponadto na podstawie uzyskanych wyników stwierdzono, że na wartość stopnia odzysku poszczególnych kongenerów PCB wpływa liczba atomów chloru wania próbki gleby techniques w cząsteczce bifenylu (Pohl, 2016). Zaobserwowano, że cięższe kongenery (PCB-52, PCB-138, PCB-153, PCB-180) zawierające od 4 do 7 atomów chloru w cząsteczce łatwiej ulegają

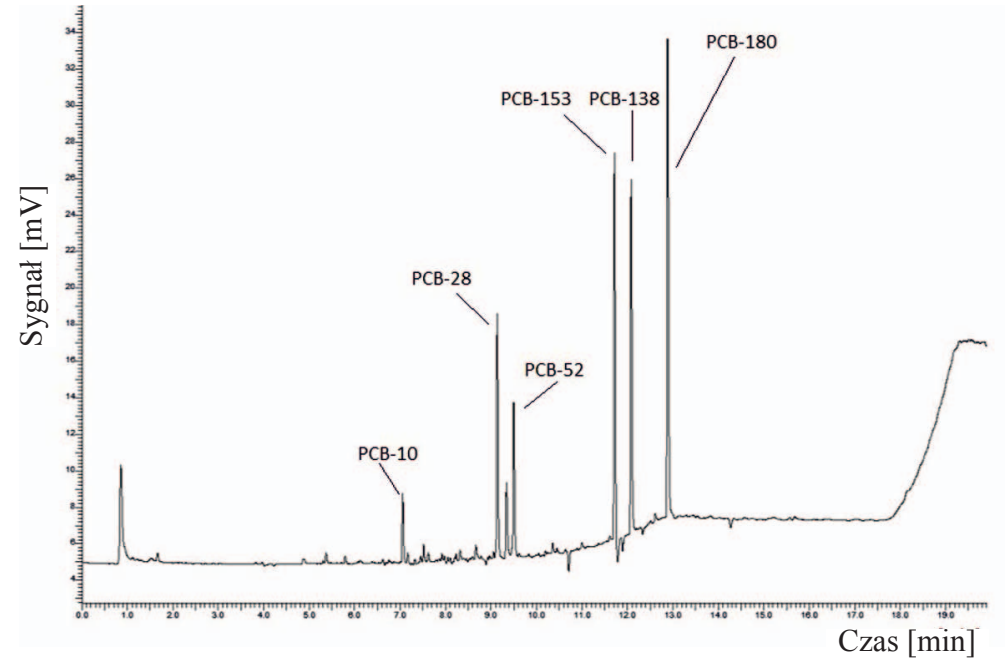

Rys. 4. Przykładowy chromatogram rozdziału kongenerów PCB we wzorcowej próbce gleby ekstrahowanej metodą ekstrakcji wspomaganej wytrząsaniem z wykorzystaniem mieszaniny rozpuszczalników n-heksan i dichlorometan w stosunku 1:1 i następnie oczyszczanej na zestawie kolumienek do ekstrakcji SPE (Silica gel nr 7086-03 i PCB-A nr 7511-04)

Fig. 4. An exemplary chromatogram for the separation of PCB congeners in a reference soil sample extracted by shaking extraction using a solvent mixture of n-hexane and dichloromethane in a ratio of 1:1 and then purified on a SPE extraction column set (Silica gel No. 7086-03 and PCB-A No. 7511-04)

Tabela 4. Wartości stopni odzysku badanych kongenerów PCB dla różnych technik przygoto-

Table 4. Values of recovery rates of the tested PCB congeners for various soil preparation

\begin{tabular}{|c|c|c|c|c|c|c|}
\hline \multirow{2}{*}{$\begin{array}{c}\text { Sposób } \\
\text { przygotowania } \\
\text { próbki }\end{array}$} & \multicolumn{7}{|c|}{ Średni stopień odzysku [\%] } \\
\cline { 2 - 7 } & PCB-10 & PCB-28 & PCB-52 & PCB-138 & PCB-153 & PCB-180 \\
\hline \hline $\mathrm{W} / \mathrm{H} / \mathrm{K}$ & 86,82 & 92,31 & 93,48 & 95,69 & 94,21 & 92,33 \\
\hline $\mathrm{W} / \mathrm{H} / \mathrm{F}$ & 85,25 & 91,41 & 93,08 & 94,89 & 93,71 & 91,63 \\
\hline $\mathrm{W} / \mathrm{HD} / \mathrm{K}$ & 87,22 & 93,14 & 93,98 & 95,99 & 94,81 & 92,73 \\
\hline $\mathrm{W} / \mathrm{HD} / \mathrm{F}$ & 86,42 & 92,49 & 93,23 & 95,13 & 94,52 & 92,39 \\
\hline $\mathrm{U} / \mathrm{H} / \mathrm{K}$ & 83,79 & 90,32 & 91,87 & 93,27 & 91,98 & 90,99 \\
\hline $\mathrm{U} / \mathrm{H} / \mathrm{F}$ & 83,08 & 89,15 & 91,43 & 93,86 & 91,11 & 90,08 \\
\hline $\mathrm{U} / \mathrm{HD} / \mathrm{K}$ & 84,85 & 91,56 & 92,74 & 93,99 & 92,62 & 91,37 \\
\hline $\mathrm{U} / \mathrm{HD} / \mathrm{F}$ & 84,15 & 91,24 & 92,37 & 93,42 & 92,22 & 90,97 \\
\hline $\mathrm{S} / \mathrm{H} / \mathrm{K}$ & 86,23 & 92,1 & 93,07 & 95,32 & 94,18 & 92,17 \\
\hline $\mathrm{S} / \mathrm{H} / \mathrm{F}$ & 85,98 & 91,96 & 93,11 & 94,88 & 93,76 & 91,72 \\
\hline $\mathrm{S} / \mathrm{HD} / \mathrm{K}$ & 86,85 & 92,26 & 93,41 & 95,62 & 94,88 & 92,75 \\
\hline $\mathrm{S} / \mathrm{HD} / \mathrm{F}$ & 86,09 & 91,52 & 92,99 & 94,64 & 93,64 & 91,42 \\
\hline
\end{tabular}

\section{Objaśnienia}

Sposób przygotowania próbki w formacie $\mathbf{X} / \mathbf{Y} / \mathbf{Z}$, gdzie: $\mathbf{X}$ - metoda ekstrakcji, $\mathbf{W}$ - ekstrakcja rozpuszczalnikiem wspomagana wytrząsaniem, $\mathbf{U}$ - ekstrakcja $\mathbf{z}$ wykorzystaniem ultradźwięków, $\mathbf{S}$ - ekstrakcja w aparacie Soxhleta, $\mathbf{Y}$ - rodzaj stosowanego rozpuszczalnika, $\mathbf{H}$ - n-heksan, $\mathbf{H D}$ - n-heksan:dichlorometan (1:1), $\mathbf{Z}$ - rodzaj kolumienek stosowanych w ekstrakcji do fazy stałej SPE, $\mathbf{K}$ - zestaw kolumienek do zadań specjalnych dedykowany do ekstrakcji PCB z gleb, F - kolumienki z wypełnieniem florisil 
wyekstrahowaniu aniżeli kongenery lżejsze (PCB-10, PCB-28). Wartości stopni odzysku lekkich kongenerów PCB kształtują się w granicach 83,08-87,22\% (PCB-10) i 89,15-93,14\% (PCB-28), podczas gdy wartości stopni odzysku kongenerów PCB zawierających od 4 do 7 atomów chloru w cząsteczce, niezależnie od metody ekstrakcji, stosowanego rozpuszczalnika i sposobu oczyszczania zawsze przekraczają 90\%.

\section{Zastosowanie metodyki chromatograficznego oznaczania PCB w próbkach środowiskowych}

W celu zastosowania opracowanej metodyki do oznaczania PCB w rzeczywistych próbkach gleb, pobrano dwie różne próbki gleby zanieczyszczone olejem transformatorowym $\mathrm{z}$ terenów południowo-wschodniej Polski. Procedurę przygotowania próbki do analizy chromatograficznej przeprowadzono wykorzystując wcześniejsze badania (Kania-Korwel i Lehmler, 2016), tzn.:

- pobieranie i wstępne przygotowanie próbki (pobrane próbki zostały doprowadzone do stanu powietrznie suchego, zmielone i przesiane przez sito o średnicy oczek $1 \mathrm{~mm}$ ); n-heksanem, po czym otrzymane roztwory zatężono do objętości $1 \mathrm{~cm}^{3}$ i poddano analizie chromatograficznej).

Analizę chromatograficzną wykonywano na chromatografie Clarus 500 firmy Perkin Elmer przy uprzednio ustalonych parametrach temperaturowych.

W wyniku analizy chromatograficznej uzyskano chromatogramy rozdziału polichlorowanych bifenyli w próbkach gleb skażonych olejem transformatorowym na podstawie których możliwe było jakościowe oznaczenie wybranych kongenerów PCB. W analityce środowiskowej, ze względów praktycznych, oznacza się jedynie tak zwane kongenery indykatorowe. Należą do nich lotne niskochlorowane kongenery PCB (PCB-28, PCB-52 i PCB-101) oraz wysokochlorowane (PCB-138, PCB-153 i PCB-180). W analizowanych próbkach udało się dodatkowo zidentyfikować 2 kongenery PCB, do których należą: PCB-10 i PCB-209. Korzystając z równań krzywych kalibracyjnych oraz biorąc pod uwagę zagęszczenie badanych ekstraktów obliczono zawartość zidentyfikowanych kongenerów PCB w rzeczywistych próbkach gleb wyrażoną w $\mu \mathrm{g} / \mathrm{kg}$ s.m. (tab. 4). Przykładowy chromatogram rozdziału polichlorowanych bifenyli w rzeczywistej próbce gleby przedstawiono na rysunku 5 .

- ekstrakcja analitów z matrycy (5 g suchej gleby umieszczono w erlenmajerce o pojemności $200 \mathrm{~cm}^{3}$. Do każdej z próbek gleb dodano $0,5 \mathrm{~g}$ sproszkowanej miedzi, w celu usunięcia związków siarki oraz $40 \mathrm{~cm}^{3}$ rozpuszczalnika (mieszanina n-heksanu i dichlorometanu w stosunku 1:1), po czym szczelnie zamknięto kolbki korkiem. Badane próbki ekstrahowano metodą ekstrakcji za pomocą rozpuszczalnika wspomaganej wytrząsaniem przez $4 \mathrm{~h}$. Uzyskany w ten sposób ekstrakt następnie przesączono przez sączek i zagęszczono);

- oczyszczanie próbki z substancji przeszkadzających (zagęszczone ekstrakty poddano oczyszczaniu wykorzystując technikę ekstrakcji do fazy stałej SPE. Do oczyszczenia wykorzystano zestaw kolumienek firmy Bakerbond dedykowany do analizy PCB z olejów transformatorowych i gleb silnie zanieczyszczonych, składający się z dwóch kolumienek: Silica gel nr 7086-03 oraz PCB-A nr 7511-04. Zaadsorbowane na kolumienkach anality eluowano

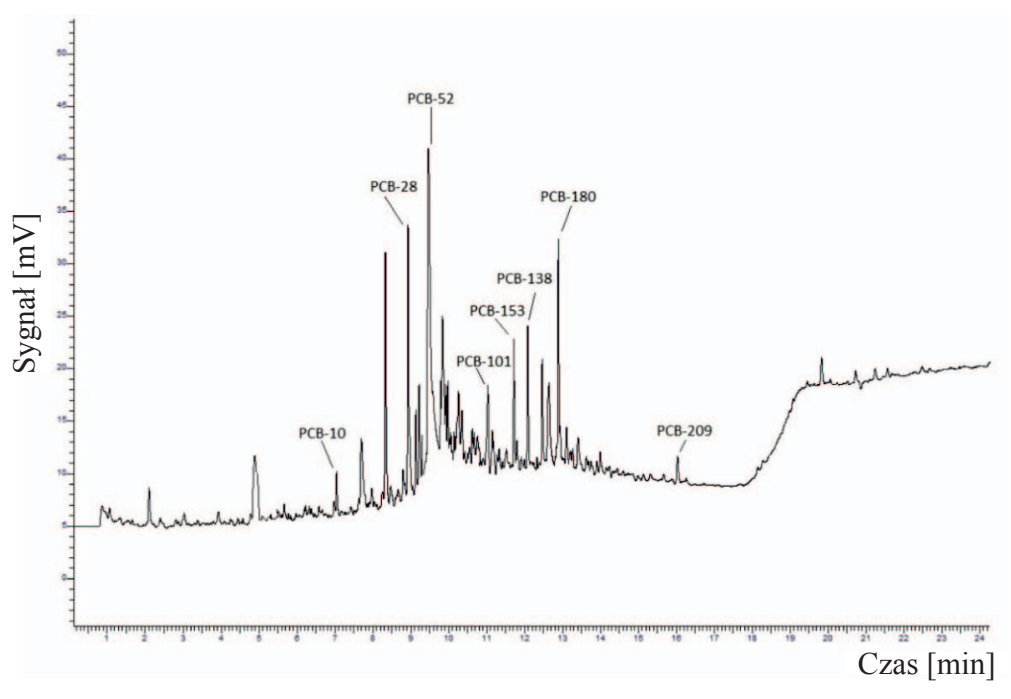

Rys. 5. Chromatogram rozdziału polichlorowanych bifenyli w rzeczywistej próbce gleby nr 1 zanieczyszczonej olejem transformatorowym pobranej z terenów południowo-wschodniej Polski

Fig. 5. Chromatogram of the distribution of polychlorinated biphenyls in the real soil sample No. 1 contaminated with transformer oil taken from the areas of south-eastern Poland

Tabela. 5. Zawartość zidentyfikowanych kongenerów PCB w próbkach środowiskowych

Table. 5. The content of identified PCB congeners in environmental samples

\begin{tabular}{|c|c|c|c|c|c|c|c|c|c|}
\hline \multicolumn{2}{|c|}{ Kongener PCB } & PCB-10 & PCB-28 & PCB-52 & PCB-101 & PCB-138 & PCB-153 & PCB-180 & PCB-209 \\
\hline \hline & \multirow{2}{*}{ próbka nr 1 } & 82,366 & 686,610 & 1578,811 & 195,104 & 150,107 & 152,107 & 118,104 & 13,248 \\
& $\pm 5,319$ & $\pm 43,445$ & $\pm 97,861$ & $\pm 12,334$ & $\pm 9,340$ & $\pm 9,555$ & $\pm 7,216$ & $\pm 0,850$ \\
\cline { 3 - 9 } Zawartość & & 40,021 & 1488,548 & 2815,502 & 127,064 & 101,470 & 122,337 & 41,242 & 8,601 \\
[ $\mu$ g/kg s.m.] & \multirow{2}{*}{ próbka nr 2 } & $\pm 2,584$ & $\pm 94,188$ & $\pm 174,516$ & $\pm 8,033$ & $\pm 6,314$ & $\pm 7,685$ & $\pm 2,520$ & $\pm 0,552$ \\
\hline
\end{tabular}


Na podstawie wyników uzyskanych dzięki analizie chromatograficznej zaobserwowano, że w rzeczywistych próbkach gleb skażonych zestarzałym olejem transformatorowym w przeważającej ilości występuje PCB-52 (1578,811 $\pm 97,861 \mu \mathrm{g} / \mathrm{kg}$ s.m. - próbka nr 1;2815,502 $\pm 174,516 \mu \mathrm{g} / \mathrm{kg}$ s.m. - próbka nr 2). Odnotowano również wysokie stężenie PCB-28 wynoszące $686,610 \pm 43,445 \mu \mathrm{g} / \mathrm{kg}$ s.m. w próbce $\mathrm{nr} 1$ oraz $1488,548 \pm 94,188 \mu \mathrm{g} / \mathrm{kg}$ w próbce $\mathrm{nr} 2$. Ponadto zaobserwowano, że w badanych próbkach gleb zawartość ciężkich kongenerów PCB zawierających powyżej 4 atomów chloru w swojej cząsteczce jest zdecydowanie niższa i maleje wraz ze wzrostem liczby atomów chloru w cząsteczce bifenylu (od 195,104 $\pm 12,334 \mu \mathrm{g} / \mathrm{kg} \mathrm{s.m}$. (próbka nr 1) i $127,064 \pm 8,033 \mu \mathrm{g} / \mathrm{kg}$ s.m. (próbka nr 2) w cząsteczce zawierającej 5 atomów chloru do 13,248 $\pm 0,850 \mu \mathrm{g} / \mathrm{kg} \mathrm{s.m}$. (próbka nr 1) i 8,601 $\pm 0,552 \mu \mathrm{g} / \mathrm{kg}$ s.m. (próbka nr 2) w cząsteczce zawierającej 10 atomów chloru).

\section{Podsumowanie}

1. Wykorzystanie metody chromatografii gazowej z detektorem ECD do identyfikacji kongenerów PCB umożliwia uzyskanie precyzyjnych oznaczeń analitów w próbkach środowiskowych.

2. Opracowana metodyka oznaczania polichlorowanych bifenyli metodą chromatografii gazowej z detekcją ECD umożliwia wykonywanie oznaczeń wybranych kongenerów PCB w szerokim zakresie stężeń.

3. Przeprowadzona walidacja układu chromatograficznego z wykorzystaniem certyfikowanych roztworów wzorcowych zawierających wybrane kongenery PCB gwarantuje wysoką dokładność i powtarzalność uzyskanych wyników.

4. Wysokie wartości odzysku analitów oraz selektywny rozdział poszczególnych kongenerów PCB na kolumnie chromatograficznej świadczą o prawidłowo opracowanej metodyce przygotowania próbek gleb zanieczyszczonych polichlorowanymi bifenylami do analizy chromatograficznej z wykorzystaniem detektora wychwytu elektronów (ECD).

5. Najwyższe wartości stopni odzysku analitów uzyskano przy zastosowaniu ekstrakcji rozpuszczalnikiem wspomaganej wytrząsaniem z wykorzystaniem mieszaniny rozpuszczalników n-heksanu i dichlorometanu w stosunku 1:1 i oczyszczaniu otrzymanych ekstraktów na zestawie kolumienkach do zadań specjalnych (Silica gel nr 7086-03 oraz PCB-A nr 7511-04).

6. Opracowana metodyka pozwala na ilościowe i jakościowe oznaczenie wybranych kongenerów polichlorowanych bifenyli w glebie zanieczyszczonej substancjami ropopochodnymi. Możliwość ilościowego oznaczenia PCB w szerokim zakresie stężeń pozwoli w przyszłości na wykorzystanie opracowanej metodyki w badaniach dotyczących przebiegu biodegradacji polichlorowanych bifenyli, zobrazowania szybkości procesu biodegradacji oraz określenia stopnia biodegradacji PCB przez biopreparat.

Artykuł powstał na podstawie pracy statutowej pt.: Ocena możliwości zastosowania chromatografii gazowej z detektorem $E C D$ do oznaczania PCB w próbkach gleby - praca INiG - PIB na zlecenie MNiSW, nr zlecenia: 0005/KE/18, nr archiwalny: DK-4100-0005/18.

\section{Literatura}

Erickson M.D., 1997. Analytical Chemistry of PCBs. Second Edition. Lewis Publishers.

Faroon O., Ruiz P., 2016. Polychlorinated biphenyls: New evidence from the last decade. Toxicology and Industrial Health, 32(11): 1825-1847. DOI: $10.1177 / 0748233715587849$.

Ficek A., Czupioł J., 2018. PCB - szkodliwe ksenobiotyki w środowisku. Środowisko, 5: 28-31.

Grochowalski A., 2003. Praktyczne aspekty rozwiązywania problemów oznaczania ultraśladowych, szkodliwych związków organicznych na przykładzie dioksyn. http://www.dioksyny.pl/wp-content/ uploads/Dioksyny_oznaczanie_2003.pdf (dostęp: 21.08.2018).

Halfadji A., Touabet A., Badjah-Hadj-Ahmed A., Comparison of Soxhlet Extraction, Microwave-Assisted Extraction and Ultrasonic Extraction for the Determination of Pcbs Congeners in Spiked Soils by Transformer Oil (ASKAREL). International Journal of Advances in Engineering \& Technology, 2013, 5(2): 63-75.

Kania M., Janiga M., 2011. Elementy walidacji metody analitycznej oznaczania w mieszaninie gazowej związków węglowodorowych oraz $\mathrm{N}_{2}, \mathrm{O}_{2}, \mathrm{CO}$ i $\mathrm{CO}_{2}$ za pomocą dwukanałowego, zaworowego chromatografu gazowego AGILENT 7890A. Nafta-Gaz, 11: 812-824.

Kania-Korwel I., Lehmler H.J., 2016. Toxicokinetics of chiral polychlorinated biphenyls across different species - a review. Environmental Science and Pollution Research, 23(3): 2058-2080. DOI: $10.1007 / \mathrm{s} 11356-015-4383-0$.

Kluk D., Steliga T., 2017. Efektywna metoda identyfikacji zanieczyszczeń ropopochodnych (TPH) i wielopierścieniowych węglowodorów aromatycznych (WWA) w glebach. Nafta-Gaz, 7: 488-495. DOI: $10.18668 / \mathrm{NG} .2017 .07 .06$.

Kruszewska M., 2018. Walidacja metod analitycznych w formacji. http://laborant.pl/index.php/walidacja-metod-analitycznych-wfarmacji (dostęp: 9.10.2018).

Lászlova K., Dudášová H., Olejniková P., Horváthová G., Velická Z., Horváthová H., Dercová K., 2018. The Appliction of Biosurfactants in Bioremediation of the Aged Sediment Contaminated Biphenyls. Water Air Soil Pollut, 229: 219. DOI 10.1007/s11270-018-3872-4.

Lehmler H.J., Harrad S.J., Huhnerfuss H., Kania-Korwel I., Lee C.M., Lu Z., Wong C.S., 2010. Chiral polychlorinated biphenyl transport, metabolism, and distribution: a review. Environ Sci. Technol., 44: 2757-2766. DOI: 10.1021/es902208u.

Lehmler H.-J., Robertson L.W., 2001. Atropisomers of PCBs, w PCBs: recent advances in environmental toxicology and health effects. W: Robertson L.W., Hansen L.G. (red.): 61-65. The University Press of Kentucky.

Oznaczanie polichlorowanych difenyli (PCB), 2018. http://www.polymer-carbon.ch.pwr.edu.pl/instrukcje/CGAnalizaPCB.pdf (dostęp: 9.10.2018). 
Pohl A., Czupioł J., Michalski R., 2016. Wpływ metod ekstrahowania polichlorowanych bifenyli z próbek środowiskowych na miarodajność uzyskiwanych wyników analitycznych, Chem. Environ. Biotechnol., 19: 73-77. DOI: 10.16926/cebj.2016.19.09.

Saija E., Mangano V., Casale KE.., La Torre G.L., Dugo G., Salvo A., 2016. Determination and quantification of PCBs, POCs and PAHs in Thunnus thynnus from the Straits of Messina (Italy). Data in Brief, 7: 129-134. DOI: 10.1016/j.dib.2016.02.027.

Stella T., Covinoa S., Burianová E., Filipová A., Křesinová Z., Voříšková J., Větrovský T., Baldrian P., Cajthaml T., 2015. Chemical and microbiological characterization of an aged PCB-contaminated soil. Science of the Total Environment, 533: 177-186. DOI: 10.1016/j.scitotenv.2015.06.019.

Szlęk M., Król A., 2013. Opracowanie metody analitycznej oznaczania siloksanów w biogazie. Nafta-Gaz, 11: 851-857.

Śliwka I., 2014. Detektor wychwytu elektronów (ECD). Podstwy teoretyczne i przykłady zastosowań. Wydawnictwo Bezkresy Wiedzy.

Ševĉík J., 1976. The Electron Capture Detector (ECD). Journal of Chromatography Library, 4: 72-86. DOI: 10.1016/S0301-4770 (08)60432-7.

Tian L., Han F., Cai Y., Kong C., Shi Y., Wang Y., Yang G., Zhan Q., Huang D., 2016. Determination of 7 Indictor Polychlorinated Biphenyls (PCBs) Residues in Porphyra by Ultrasonic Extraction and Gas Chromatography (GC). Journal of Agricultural Chemistry and Environment, 5: 1-5. DOI: 10.4236/jacen.2016.51B001.

Vane C.H., Kim A.W., Beriro D.J., Cave M.R., Knights K., MossHayes V., Nathanail P.C., 2014. Polycyclic aromatic hydrocarbons (PAH) and polychlorinated biphenyls (PCB) in urban soils of Greater London, UK. Applied Geochemistry, 51: 303-314. DOI: 10.1016/j.apgeochem.2014.09.013.
Vazquez-Roig P., Pico Y., 2015. Pressurized liquid extraction of organic contaminants in environmental and food samples. Trends in Analytical Chemistry, 71: 55-64. DOI: 10.1016/j.trac.2015.04.014.

Witkiewicz Z., 2005. Podstawy chromatografii. WNT, Warszawa. ISBN: 83-204-3089-5.

Wojtowicz K. 2018. Opracowanie metodyki oznaczania BTEX w próbkach gleb z wykorzystaniem chromatografii gazowej z przystawką headspace. Nafta-Gaz, 3: 201-207. DOI: 10.18668/ NG.2018.03.03.

Zhang X., Li F., Liu T., Peng C., Duan D., Xu C., Zhu S., Shi J., 2013. The Influence of Polychlorinated Biphenyls Contamination on Soil Protein Expression. Hindawi Publishing Corporation ISRN Soil Science, 2013: 6. DOI: 10.1155/2013/126391.

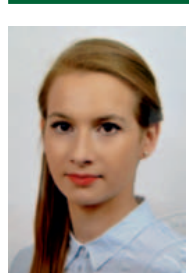

Mgr Katarzyna WOJTOWICZ

Asystent w Zakładzie Technologii Eksploatacji

Płynów Złożowych

Instytut Nafty i Gazu - Państwowy Instytut Badawczy ul. Lubicz 25 A

31-503 Kraków

E-mail: katarzyna.wojtowicz@inig.pl

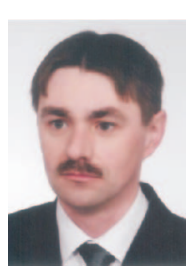

Mgr Piotr JAKUBOWICZ

Starszy specjalista badawczo-techniczny w Zakładzie Technologii Eksploatacji Płynów Złożowych Instytut Nafty i Gazu - Państwowy Instytut Badawczy ul. Lubicz 25 A

31-503 Kraków

E-mail: piotr.jakubowicz@inig.pl

\section{OFERTA BADAWCZA ZAKŁADU} TECHNOLOGII WIERCENIA

- $\quad$ opracowywanie składów i technologii sporządzania płuczek wiertniczych, cieczy do dowiercania, opróbowania i rekonstrukcji odwiertów, zaczynów cementowych i mieszanin wiążących dla różnych warunków geologicznotechnicznych wiercenia;

- kompleksowe badania i ocena nowych rodzajów środków chemicznych, materiałów płuczkowych i wiążących, przeznaczonych do sporządzania i regulowania właściwości ptuczek wiertniczych i zaczynów cementowych;

pomiary parametrów technologicznych cieczy wiertniczych i kamienia cementowego w warunkach HPHT;

badania wptywu cieczy wiertniczych na przewiercane skały;

dobór ptuczek wiertniczych, zaczynów cementowych, cieczy buforowych w celu poprawy skuteczności cementowania otworów wiertniczych;

badania serwisowe dla bieżących zabiegów cementowania;

specjalistyczne badania laboratoryjne dotyczące oznaczania: współczynnika tarcia cieczy wiertniczych i napięcia powierzchniowego na granicy faz, czystości i temperatury krystalizacji solanek, typu emulsji, sedymentacji fazy stałej, efektywności wynoszenia zwiercin w otworach kierunkowych i poziomych oraz wyptukiwania osadów iłowych ze skał przed zabiegiem cementowania, odporności na migrację gazu w wiążącym zaczynie cementowym w warunkach otworopodobnych, wczesnej wytrzymatości na ściskanie kamienia cementowego, odporności korozyjnej kamienia cementowego w różnym środowisku złożowym, porowatości oraz przepuszczalności dla gazu kamienia cementowego i skat, zawartości związków chemicznych w cieczach wiertniczych, stopnia toksyczności środków chemicznych i cieczy wiertniczych przy użyciu bioindykatorów;

badania wtaściwości fizyczno-mechanicznych skat pod kątem ich zwiercalności.

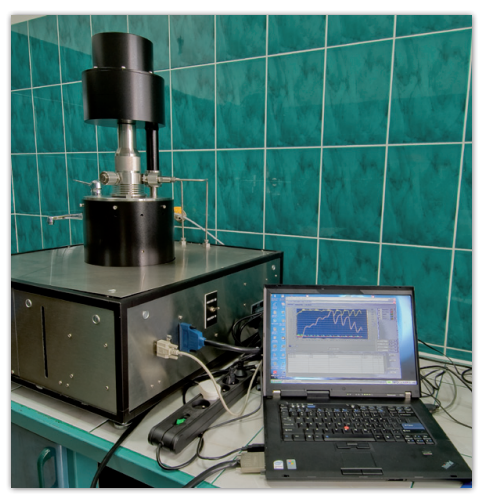

INSTYTUT NAFTY I GAZU

- Państwowy Instytut Badawczy 